\title{
New appetite for the monitoring of European forests
}

\author{
Marco Ferretti ${ }^{1}$ (D)
}

Received: 24 August 2021 / Accepted: 25 October 2021 / Published online: 12 November 2021

(c) The Author(s) 2021

\begin{abstract}
Key message Future international forest monitoring should build upon the existing pan-European programs. There is a renewed interest in the monitoring of European forests. Future monitoring systems should build upon existing international programs, making use of their strengths and solving their weaknesses. This approach will result into win-win solutions for both the existing and future systems. The UNECE ICP Forests has a number of characteristics that makes it a very good and strong basis for developing an advanced international forest monitoring system.
\end{abstract}

Keywords European forest $\cdot$ Future international monitoring $\cdot$ ICP Forests

After being quite low in the consideration of many, forest monitoring is experiencing a renewed interest in Europe. Besides the Article 9 of the NEC Directive (Directive (EU) 2016/2284 2016) containing obligation for the EU Member States to ensure the monitoring of negative impacts of air pollution upon ecosystems (including forests), there are several other important signals, for example, the recent call from the European Forest Institute on future forest monitoring (EFI 2021a; see also below), the dedicated seminar (EFI 2021b), and the Horizon Europe (see below) with at least two open calls where forest monitoring is explicitly mentioned.

The EFI call (EFI 2021a) was about "a harmonized and robust reliable European forest monitoring system," with a "conceptual framework for a harmonized European forest monitoring system (including potential barriers and synergies with existing systems) that addresses, among other aspects carbon storage, biodiversity, and health of forests." Such a system has "to support ongoing and future policy processes at the European Union level and strengthen the role that forests play in these processes."

In Horizon Europe, in one call, the "development and improvement of robust and transparent methodologies for

\section{Handling Editor: Erwin Dreyer}

Marco Ferretti

marco.ferretti@wsl.ch

1 Swiss Federal Research Institute for Forest, Snow and Landscape Research WSL, Zürcherstrasse 111, CH-8903 Birmensdorf, Switzerland high-resolution monitoring and reporting of forest carbon pools and their interactions through a combination of in-situ data collection and remote sensing methods to be used to advance land use, land-use change and forestry (LULUCF) reporting under the UNFCCC and compliance under EU legislation" is required (European Commission 2021a). In another call (European Commission 2021b), the proposal will "establish a European network to gather information on current developments in demo and long-term observation sites."

As an advocate of forest monitoring since a long while, I am particularly glad of these signals of renewed interest in the field. When considering the international perspective, Europe is in the fortunate position to have a solid ground in forest monitoring, at least in two important respects: the scientific and technical basis and the governance of international forest monitoring. The International Co-operative Programme on Assessment and Monitoring of Air Pollution Effects on Forests (ICP Forests, see http://icp-forests.net/) is exemplary in both respects, and it is unique as-unlike other initiatives-its design concept incorporates a systematic component for surveillance and early warning and a series of case studies located across forests made up by the most frequent European forest trees species for intensive, harmonized monitoring of a number of attributes (see below).

ICP Forests has been launched in 1985 under the auspices of the 1979 UN ECE Air Convention (see https:// unece.org/environment-policy/air), the first legally binding multi-lateral international instrument to combat air pollution on a regional basis. At present, 42 countries in Europe 
and beyond participate in ICP Forests, and the majority of them conducts continuous forest monitoring according to an agreed set of monitoring methodologies covering 13 different fields. Although its focus stays in understanding and reporting air pollution effects on forests, ICP Forests realized rather soon that such a focus implies considering the other possible concurring (and confounding) factors involved, from climate to management. For this reason, monitoring methods under ICP Forests cover several ecosystem compartments from atmosphere to vegetation and soil (thus including those related to carbon storage, biodiversity, and forest health). All methods have been designed to favor harmonization and serve policy needs, all are subject to continuous review and to shared quality assurance/quality control procedures, and all have been conceived to submit data to a centralized data base according to agreed procedures (http:// icp-forests.net/page/icp-forests-manual). Today ICP Forests is - among other - an international data provider for Forest Europe (see Criterion 2, Forest Europe 2020), and its plots and data contribute to the NEC Directive (Directive (EU) 2016/2284 2016).

Many knows the technical features of the program. It is based on an innovative (at the time of design in the 1980s) concept with differentiated monitoring levels. Level I consists of ca. 5800 Level I plots distributed according to a systematic transnational grid of $16 \times 16 \mathrm{~km}$ (nominal density). There, tree health is evaluated annually according to a large set of attributes, while other investigations have been carried out on a less regular, more relaxed time basis (soil) or una-tantum (foliar; diversity). A new soil survey is being designed. Level I provides data and results for Forests Europe's SOEF reports (Forest Europe 2020) and key data on European soils (e.g., Fleck et al. 2016). Level II consists of ca. 620 intensive monitoring plots located in selected forest ecosystems. There, the co-located, Europeanscale harmonized measurements of biotic and abiotic drivers and forest ecosystem's response permits to investigate status (e.g., Waldner et al. 2015), trends (e.g., Waldner et al. 2014; Johnson et al. 2018; Camino-Serrano et al. 2016) of several attributes, and drivers-response relationships (e.g., Etzold et al. 2020; Van der Linde et al. 2018) that can be expanded-even to improve national forest inventory estimates (Massey et al. in press). Without a harmonized and structured monitoring design, this would not have been possible. It is worth mentioning that in its origin, the concept included also a Level III, where ecosystem processes and fluxes were considered-today, somebody may want to use the term "supersites" to identify such a monitoring level.

Fewer knows that ICP Forests data and sites permitted $>450$ scientific publications (http://icp-forests.net/page/ scientific-publications) and that ICP Forests delivered data to dozens of applicants per year according to a very simple, yet participative, procedure.
But probably even fewer is aware of what I consider the greatest achievement of ICP Forests: its role in demonstrating the extent to which transnational forest monitoring is possible and feasible (Ferretti et al. 2013). ICP Forests started in the mid-1980s and developed during the next decade, in a phase of dramatic political changes in Europe. Despite this instability, the cooperation in the monitoring program has increased and expanded. There were several reasons for this: the framework provided by the UN ECE Air Convention, the strong political will that led to an unusually long-term support from the European Union (almost continuous, although in different forms from 1987 to 2011), the commitment, perseverance, and motivation of scientists, foresters, and national funding agencies. The governance structure with a bottom-up approach for scientific-technical issues and solutions and then a participatory official mechanism for informed decision making has been a key factor. In this way, all partners learn from all others: It has been, and continues to be, a unique opportunity from which all the other achievements stem.

With all this in mind, I found the statement that "there is a lack of European-wide harmonized and robust information on forest resources and their conditions" (EFI 2021a) not justified, and —on the other side-appreciate the intent to "reinitiate EU participation in the ICP Forests for long-term observations of forest ecosystems" (European Commission 2021b). Since the EU (at that time the European Community) is a signatory party of the Air Convention, this latter intent will be very easy to implement: Delegates from the European Commission officially attended the meetings of ICP Forests in the past and have the right and are welcome to come back in the business at any time.

Forest monitoring has a number of meanings for many, and those designing and carrying out monitoring are frequently seen as simple data providers for "real" scientists: This is an obsolete perspective since a long while, as monitoring is per se an approach to scientific investigation and it is based on own science and scientific practice (see Innes 1995; Lovett et al. 2007; Spellerberg 2005). ICP Forests is certainly far to be a perfect system: Gaps in data, inconsistencies, pending issues in data quality and estimation, and the lack of a remote sensing component are probably the weakest parts. Yet, it is my firm opinion that ICP Forests offers a very good and strong basis for developing an international forest monitoring system with a well-established ground component with a legacy of long-term and large-scale data on a range of attributes that are key to several scientific questions, and a solid, well-tested governance mechanism.

It will be a waste of intellectual and material resources (including EU financial resources and those from individual countries) if infrastructures, data, experience, and expertise of ICP Forests will be not considered when designing a future European forest monitoring system. Rather, a 
co-operation in designing a future system will potentially result into a win-win solution, with ICP Forests having the opportunity to fill its existing gaps, and the future new system the chance to profit of the existing experience and infrastructure.

Funding Open Access funding provided by Lib4RI - Library for the Research Institutes within the ETH Domain: Eawag, Empa, PSI \& WSL.

\section{Declarations}

Conflict of interest The author serves as the Chairman of the ICP Forests.

Open Access This article is licensed under a Creative Commons Attribution 4.0 International License, which permits use, sharing, adaptation, distribution and reproduction in any medium or format, as long as you give appropriate credit to the original author(s) and the source, provide a link to the Creative Commons licence, and indicate if changes were made. The images or other third party material in this article are included in the article's Creative Commons licence, unless indicated otherwise in a credit line to the material. If material is not included in the article's Creative Commons licence and your intended use is not permitted by statutory regulation or exceeds the permitted use, you will need to obtain permission directly from the copyright holder. To view a copy of this licence, visit http://creativecommons.org/licenses/by/4.0/.

\section{References}

Camino-Serrano M, Graf Pannatier E, Vicca S, Luyssaert SE, Jonard M, Ciais P, Guenet B, Gielen B, Peñuelas J, Sardans J, Waldner P, Etzold S, Cecchini G, Clarke N, Galić Z, Gandois L, Hansen K, Johnson J, Klinck U, Lachmanová Z, Lindroos A-J, Meesenburg H, Nieminen TM, Sanders TGM, Sawicka K, Seidling W, Thimonier A, Vanguelova E, Verstraeten A, Vesterdal L, Janssens IA (2016) Trends in soil solution dissolved organic carbon (DOC) concentrations across European forests. Biogeosciences 13:5567-5585. https://doi.org/10.5194/bg-13-5567-2016

Directive (EU) 2016/2284 (2016) Directive (EU) 2016/2284 of the European Parliament and of the Council of 14 December 2016 on the reduction of national emissions of certain atmospheric pollutants, amending Directive 2003/35/EC and repealing Directive 2001/81/EC Directive (EU) 2016/2284 https://eur-lex.europa.eu/ eli/dir/2016/2284/oj (Accessed on 18.06.2021)

EFI (2021a) G-01-2021: EFI network fund, towards a harmonised European Forest monitoring system. (https://efi.int/grants-train ing/grants/G-01-2021) (Accessed on 17.08.2021)

EFI (2021b) Toward next generation forest monitoring: recent developments and policy needs. https://efi.int/membership/ac/2021/progr amme0710 (Accessed on 18.08.2021).

Etzold S, Ferretti M, Reinds GJ, Solberg S, Gessler A, Waldner P, Schaub M, Simpson D, Benham S, Hansen K, Ingerslev M, Jonard M, Karlsson PE, Lindroos A-J, Marchetto A, Manninger M, Meesenburg H, Merilä P, Nöjd P, Rautio P, Sanders TGM, Seidling W, Skudnik M, Thimonier A, Verstraeten A, Vesterdal L, Vejpustkova M, de Vries W (2020) Nitrogen deposition is the most important environmental driver of growth of pure, even-aged and managed European forests. Forest Ecol Management 458:117762. https://doi.org/10.1016/j.foreco.2019.117762

European Commission (2021a) HORIZON-CL5-2021-D1-01-09. The contribution of forest management to climate action: pathways, trade-offs and co-benefits", https://ec.europa.eu/info/fundi ng-tenders/opportunities/portal/screen/opportunities/topic-details/ horizon-c15-2021-d1-01-09). (Accessed on 17.06.2021)

European Commission (2021b) HORIZON-CL6-2022-CLIMATE-01-05. Forestry - European observatory of climate change impacts and demonstration network of climate smart restoration pilots", https://ec.europa.eu/info/funding-tenders/opportunities/ portal/screen/opportunities/topic-details/horizon-cl6-2022-clima te-01-05) (Accessed on 17.06.2021).

Ferretti M, Fischer R, Moffat A J (2013) Terrestrial methods in forest monitoring: toward the next generation? M Ferretti R Fischer Eds Forest Monitoring DENS UK Elsevier 12:481-496

Fleck S, Cools N, de Vos B, Meesenburg H, Fischer R (2016) The Level II aggregated forest soil condition database links soil physicochemical and hydraulic properties with long-term observations of forest condition in Europe. Ann for Sci 73:945-957. https://doi. org/10.1007/s13595-016-0571-4

FOREST EUROPE, 2020: State of Europe's Forests 2020.

Innes JL (1995) Design of an intensive monitoring system for the Swiss forests. In: Beniston M (ed) Mountain environments in changing climates. Routledge, London, New York, pp 227-241

Johnson J, Graf-Pannatier E, Carnicelli S, Cecchini G, Clarke N, Cools N, Hansen K, Meesenburg H, Nieminen TM, Pihl Karlsson G, Titeux H, Vanguelova E, Verstraeten A, Vesterdahl L, Waldner P, Jonard M (2018) The response of soil solution chemistry in European forests to decreasing acid deposition. Glob Change Biol 24:3603-3619. https://doi.org/10.1111/gcb.14156

Lovett G M, Burns D A, Driscoll C T, Jenkins J C, Mitchell M J, Rustad L, Shanley J B, Likens G E, Haeuberet R (2007) Who needs environmental monitoring? Front Ecol Environ, 2007.

Massey A, Lanz A, Ferretti M (2021) A design-based assessment of an expanded set of auxiliary sources for forest change estimation. Can J For Res 51:1-12. https://doi.org/10.1139/cjfr-2020-0529

Spellerberg I F (2005) Monitoring Ecological Change. $2^{\text {nd }}$ edition. Cambridge University Press, Cambridge, UK. https://doi.org/10. 1017/CBO9780511614699

UN ECE (2021) Air. https://unece.org/environment-policy/air (Accessed on 18.08.2021).

Van der Linde S, Suz LM, Orme CDL, Cox F, Andreae H, Asi E, Atkinson B, Benham S, Carroll C, Cools N, de Vos B, Dietrich H-P, Eichhorn J, Gehrmann J, Grebenc T, Gweon HS, Hansen K, Jacob F, Kristöfel F, Lech P, Manninger M, Martin J, Meesenburg H, Merilä P, Nicolas M, Pavlenda P, Rautio P, Schaub M, Schröck H-W, Seidling W, Srámek V, Thimonier A, Thomsen IM, Titeux H, Vanguelova E, Verstraeten A, Vesterdal L, Waldner P, Wijk S, Zhang Y, Žlindra D, Bidartondo MI (2018) Environment and host as large-scale controls of ectomycorrhizal fungi. Nature 558:243-248. https://doi.org/10.1038/s41586-018-0189-9

Waldner P, Marchetto A, Thimonier A, Schmitt M, Rogora M, Granke O, Mues V, Hansen K, Pihl Karlsson G, Zlindra D, Clarke N, Verstraeten A, Lazdins A, Schimming C, Iacoban C, Lindroos A-J, Vanguelova E, Benham S, Meesenburg H, Nicolas M, Kowalska A, Apuhtin V, Nappa U, Lachmanova Z, Kristoefel F, Bleeker A, Ingerslev M, Vesterdal L, Molina J, Fischer U, Seidling W, Jonard M, O'Dea P, Johnson J, Fischer R, Lorenz M (2014) Detection of temporal trends in atmospheric deposition of inorganic nitrogen and sulphate to forests in Europe. Atmos Environ 95:363374https://doi.org/10.1016/j.atmosenv.2014.06.054

Waldner P, Thimonier A, Graf Pannatier E, Etzold S, Schmitt M, Marchetto A, Rautio P, Derome K, Nieminen TM, Nevalainen S, Lindroos A-J, Merilä P, Kindermann G, Neumann M, Cools N, de Vos B, Roskams P, Verstraeten A, Hansen K, Pihl Karlsson 
G, Dietrich HP, Raspe S, Granke O, Fischer R, Iost S, Lorenz M, Sanders TGM, Michel A, Nagel H-D, Scheuschner T, Simončič $\mathrm{P}$, von Wilpert K, Meesenburg H, Fleck S, Ingerslev M, Gundersen P, Stupak I, Vesterdal L, Jonard M, Nicholas M, Clarke N, Benham S, Vanguelova E, Potočič N, Minaya M (2015) Exceedance of critical loads and of critical limits impacts tree nutrition across Europe. Ann for Sci 72:929-939. https://doi.org/10.1007/ s13595-015-0489-2
Publisher's note Springer Nature remains neutral with regard to jurisdictional claims in published maps and institutional affiliations. 